\title{
Sovereign Between Homogeneity and the Social Diversity - Discourse on the Ideas of J. S.
}

\author{
Eriseld Kalemaj \\ kalemaj. eriseld@yahoo.com \\ University "Fan S. Noli" Korçë, Albania \\ Faculty of Human and Natural Sciences \\ Department of Social Sciences
}

\begin{abstract}
In the context of political philosophy, one main issue that needs to be discussed is the notion of "sovereign". The focus will be on the debate created following Rousseau's theory and the French Revolution. In this article, we pay attention to the philosophical controversial that the famous English philosopher J. S. Mill $(1806-1873)$ displays as a well-known author of utilitarianism and as a precursor of liberalism. This discourse rises above the trend to deduce society and in this logic, it is justified the sovereign as an embodiment of unity on one hand, and on the other one, it is the action on the dynamic condition of society or the problem of individual freedom. The question that rises here is on how legitimate will be the political power in a comprehensive decision if it will violate the freedom of just one of the subjects of society. Thus, the efforts should be oriented to the way the political power is brought which will create a particular culture on doing politics. In this sense we should ask about the profile that a sovereign should have. Trying to understand this kind of profile, we should see the sovereign in a "triangle" of factors, such as: the community (custom or public opinion); the power (objective representative of society); and freedom of the individual (the moral subject).
\end{abstract}

Keywords: sovereign, social objectification, public opinion, individual freedom

\section{Introduction}

The political philosophy behind the theory of Rousseau, which inspired French Revolution (1789 - 1799), motivated a different kind of discourse in the meaning of "Sovereign". In this environment were positioned some optics, which will comprise all the political discussion until our days. Communitarianism theory, historical and cultural concept of sovereign highlighted a fundamental problem. Subjective freedom, unique of the members inside a society made a serious obstacle in the creation of social objectivity, the objectivity that justifies the political power. Difficulty to measure the society in its totality became issue for giving solutions. This subject is treated extensively and profoundly by John S. Mill (1806-1873). Therefore, in this paper, in the 210 anniversary of his birth we will discuss the ideas that came today as actual.

Different theories used certain logics, to bring the sense of the sovereign power in the way of formal logic (deduction). Worth mentioning is the analytical philosophy, which is own focus puts in achieving clarity, objectification and measurable validity in empiric aspect. In this line is also utilitarianism, which distanced itself from the historical or cultural factor. This philosophy connects closely political power and political organization of the society on the bases of measurable criteria, which are found outside subjective condition. So, on the basis of objective criteria, that justifies and determines the human behaviour. Natural, philosophical and psychological meaning of human being must be the only foundation, from where to take life the sovereign. In some way, this was a return to the laws of nature. Empiric viewpoint emphasised mostly from British philosophy or baconian model, approached in political theory of T. Hobs.

Starting from the criteria of usefulness, classical utilitarianism (or classical liberalization) reduces the human meaning as perceptive being and psychological. On this premise, society becomes one, and according to the calculative logic of Bantam, what it was the benefit of all members of society had the tagger of power. 


\section{Freedom and the value of individual}

"The critic" and in the same time continuer of this philosophical stream, John Stuart Mill didn't think the man was an object. From this premise, through mathematical logic is objectivized the society. From here we can create a measurable power and concise in his acts. Psychological state recognition (sensorial) it doesn't provide enough understanding of human nature. The human is distinguished from the natural condition, not only from the reason, but because he is free to choose. Choose not the tools, but the goals. This should be clearly differentiated! He is potential being, dynamic, subjective authentic, vital with sublime goals, so, variable and distinctive from his own human kind. Therefore, the judgment only in the perceptive condition would be a naivety, because considers the human in his biological aspirations.

With this, Mill exceeded the hedonism of Bentham, referring to the most intellective character pleasures and existential. Thus, the Bentham's relativism became a strong argument for the opponents of utilitarianism, with the dimension of the Mill's philosophy differs character.

In the notion of Mill "freedom" is highly a treaty over "individualism". Individual freedom is understood like an independent entity, but not isolated. The human is a being that opens towards the world, by creating himself. The notion "Eccentric" (Mill, on freedom, 85), term borrowed from astrophysics illustrate the meaning of individuality. The subject is the center from where is created the world, displays it as reality and this reality influences on the whole human cosmos where he belongs. At this opening arises always something new, which sublimes the simple fact of being human. Consequence of this is that value that Mill glorifies; social diversity and the variety of life experiences. So, the society should not be understood as individual relativity (Bentham), but as a plural community (Mill).

However, for Mill, the society in general is composed of members in perceptive condition. They remain superficial in lifestyle, thus forming a naive opinion or that is noun like "public opinion". Inside the social contests, should be evaluated the individual, like the being that creates an authentic universe, that goes behind the usual situation, or the pressure of general opinion. For this reason, Mill had his remarks on the democratic Sovereign form that motivated Bentham.

\section{The relationship public opinion - political power and the position of individual}

Sovereign majority is measured or is equal with the public opinion. In this sense, it is objectivized to general opinion. Social average becomes the main reference to indicate incentives and trends. In this meaning, sovereign "is dressed" with the authority of public opinion and his action is materialized like juridical and political act. As a constant condition, social contests, so the sovereign isn't a created authority but is attributed as given. The sovereign's the reason is the reason of the majority of society, an authority that is explained with the terms of conservatoires.

However, the public opinion is an "abstract phantasm" impersonal power that becomes indifferent to the particular circumstances. So, is other thing from the concrete public? Inspired from this force, the sovereign is transformed into identic power with collective mediocrity. This is what Mill's call "sovereign crowd" (Mill, 2014, p. 84), the way how democracy degenerates into ochlocracy.

But, we don't have to forget that "Over himself, over his body and mind, the individual is sovereign" (Mill, 2014, 16). The power of naïve majority has the right to rule and limit each individual, despite differences, that can have with the community conditions which is part. In this midst, the individual is not treated like value but as an object. He lost in crowd and with this he loses his self-identity. He identifies with the whole, by objectivizing his being. His own life is held by the others and is extinguished in him each original creation. He resigns himself to society, becoming like the others. Its internal value, subdues to the identification with the whole. In this sense, he becomes conformist, which imitates and passively accepts to subject to an abstract principle. So, "the individual sovereign" is pressed, because the majority objectivized the authentic subjects. This is an expression of human denaturation.

Thus, democracy as the domination of the people doesn't work, because those that have the power are not equivalent with those that pretend to self-directed. The individual necessarily obeys to one authority that does not come naturally, from his right over himself. Reasoned in this way, the sovereign becomes the opposite of what individual aspire. Social system cannot respond to diverse circumstances and situations. Social context can be precise in definitions, but it remains for 
ordinary people, therefore inadequate to unique characters. Therefore, the utilitarianism of Bentham, through categorical judgments justifies a generalizing power, which is essentially violent.

The sovereign as reference to the opinion or to the amount of interests with communitarian comprehensive it is unduly deferential. The whole individual potential is technic zed through mathematical logic. "Theories of Social Selections" in this point is raised the question; with what right a community (suppose the voters) realize the unification of the interest, goals, quite different judgments to each of its members? Meanwhile, that its decisions could unfairly oppress minority potentials or certain individualities, as the result of this homogenous unification and galvanic? In other words, the problem lays in the diverse nature of society and political power, on the other hand, political power acts by thinking as a standard body, objective.

Then we must accept that any restriction of freedom is harmful?! The authorities are not fair and so it is best to ignore political and social power, by pretending for an anarchic rapport to community life. But will we guarantee the freedom of everyone?

\section{Minimalist state and the sovereign profile}

From what we discussed, sovereign stands between social homogeneity (objectivity), from where the source of power and freedom (diversity) of individualities where he must act. The problem appearing is that political power is justified in principle; however, concrete environment in which it operates if will use the same logic, it would be contrary with the principle of sovereign. In this contradictory situation, the issue is, how should behave the political power? Under the conditions where a human is not a consistent and constant, where a member of majority who has decided in a certain moment, may change its position; Must the sovereign relies entirely on the reason of majority or should be adapted with the real conditions where it acts? So, how we should create a political system not only sustainable, but also right and functional?

Subjection to the public opinion is the easiest choice; generally, many of you think the individuality as a factor which complicates and greatly complicates the disintegration of social objectivity achievement. Thus, the uniqueness of the individual will always be in a confrontation with social sustainability. The challenge is to escape the hardness of the public in general. To these forces is manifested the personal progress, but also the originality of the human being. Therefore for Mill, we need to define a clear space that "... which is the limit of the right sovereignty of the individual over himself? Where begins the social power? In what extent life belongs to human individuality and in what to the society?" (Mill, 2014, p. 94)

At the beginning of humanity, the spontaneity and individuality was expressed intensively. The criterion reference or certain behaviours were missing, by creating a space action that remained to the coincidence. This was the moment of freedom that created confusion. Therefore, society as a whole, as unique and objective needed to fight this spontaneity. Precisely, to this purpose was born necessity of a power that organizes, directs and focuses the individuals in a particular behaviour. Under this reasoning, the law and rule is one that basically holds the power to structure human relationships. So, to make them more restrained, to cultivate the culture of the law and certain social norms. The society and the power that it creates, maintains the control of all individual impulses, obligates every person to create a similar and uniform attitude like everyone else. Until here, we haven't said anything more than, Hobbes' said, etc.

The criteria should be freedom of the individual. As we expressed above, it is not about the freedom of the will. Mill talks about the possibility of a qualitative freedom and space, where everyone can create his subjective reality. The boundary of this freedom is not impaired and the reciprocal obligation with others. Out of this contest ".... his freedom is absolute right" (Mill, 2014, p. 16). Important to note is; referring the respect to the freedom and uniqueness of every individual to go towards unity and community life. In this relationship, eventually is distinguished where is the limit of the authority society, how far goes the action of "the sovereign individual" in relation to himself. Therefore, reciprocity is taking responsibility and appropriating some tasks in social behaviour. Regarding the private behavioural and completely unrelated to the interests of society, the individual is not responsible for others, but at the moment that harms another space, there he is responsible. At this relationship takes life morality and law. There when is harmed the space of the individual or of the community, the sovereign becomes active.

Clearly are distinguished individualism and the obligations of social human. In this sense, the individualism doesn't mean egoism or indifferentism. So, his focus is in creating clear civil and social boarders that should motivate the individuality. 
"...So, the nature and limits of the power that society may lawfully exercise over the individual" (Mill, 2014, p. 5). This power can restrict every aspect of life, except those that belong to him and only him, so, to the individual. On the basis of this criterion, the sovereign has the clear extent, duties and functions. In the opposite case, so, to the violation of the freedom, aiming to more power extension or inaction of power (not fulfilling the duty of the sovereign) it gives prerogative everyone for rebellion and rejection (resistance) over the power.

To protect the freedom of how individual realizes himself, the political power is reduced in his own defense, against violation of this space from the other or the community in general. So, political factor should be minimalist in his own subjects' life. If the sovereign intervenes, he must maintain control of the malicious nature that everyone has inside. So, to avoid his animal nature and his own selfish purposes, who does not care about the consequences of his action? Mostly, the sovereign has the primary obligation to guarantee the development of each show of individualism, which does not affect the coexistence with the other. Regarding the aspects that are not his prerogative, it would be excessive and unjust as power. So, the sovereign is not comprehensive and absolute against his own subjects. Referring to this postulate, should be guaranteed freedom of thought and expression, freedom to create individuality. Briefly, everyone to create his own world, so, to realize himself according to his abilities, character, passions, inclination or desire, of course up to the limits that has no damaging consequences for others. In the end political behavior or condition community should realize that ".... It is essential that different people be allowed to live different lives" (Milli, 2014, p. 80).

\section{Sovereign as an expression of statecraft}

Despite from what we discussed, we cannot determine clearly the exact boundaries of political power. The human and his circumstances are so complex, that it is impossible to make an accurate distinction of the right of individual and the public law. The human will inevitably be in society and his individuality is associated with other individualities. Thus, in one way or another they will have to lose from their liberty. Then, the individual liberty is always in dangerous situations. But why is it so? What endanger to the extreme?

There are several reasons for this; first, the trend for more power to ourselves and that later to impose on others, second, the conformism due to social status (public opinion). The third reason which is related with the first two is the mentality that lifestyle issues must have one solution and only one. This is a moment where predominates a certain power, that as saying it owns the truth and out of this truth, you will be eliminated, abandoned, averted or otherwise "legitimize" enforcement masses. This is the road of tyranny, but also form of her expression. This would be a naive simplification, because life is irreducible, and the truth is complex. Two principles of Mill, which he never abandoned!

When political power is in synchrony with public opinion, it is more damaging. Opinion becomes overwhelming for any expression of individuality, hermetic and categorical in his domination. Collective mentality refuses to accept even the slightest error of it, even refusing to talk over. As well, not every individual has the prerogative of the truth. What should be done is to create a discussion environment - plural. "People and governments must act on the basis of their best ability. Absolute security does not exist, but exists enough certainly for the purposes of human life" (Milli, 2014, p. 26). Intersubjective conduction synthesizes interests, experiences, goals. .... Where every party is corrected, reaching a harmony of antagonisms between individual, society and political behaviour. In this way the society makes progress. Its dogmas do not remain solid. The individual understands and experience new experiences. Political power does not stand as a constant power, but is adapted to the pace and dynamics of the subjects in which it operates. Therefore, the sovereign cannot be the master of the truth (like operates the public opinion). He may not be a competent in all matters, which means, he has to listen, discuss before take decisions. By fleeing from abstract generalisation, sovereign decides to take into account the special circumstances, every individuality, and specific situation. Occurred in this moment of discussion, the best question will be this of Schiler "How we can achieve harmony without creating uniformity?" (Moggach, 2007, p. 7) The key is found in the notion "Harmony" The challenge of the sovereign is to create equilibrium in a society characterized by diversity, change and dynamics. For this reason, Michael Joseph Oakeshott sees that the sovereign is not juridical issue, nor the work of a concise logical, such as claims analytical philosophy, positivists, empiricism, realists. As well, is not a moral issue, custom or historical authority, how communitarian think, multiculturalists, conservationists, etc. ? Sovereign is the expression of the art of governance to ensure this harmony. 


\section{Conclusion}

Holy for Mill is the freedom of individual. Therefore, he was against every kind of oppression starting from uniformity, tradition, public opinion, juridical systems or political power. More we add metaphysic, abstraction, rationality, institution, law, bureaucracy and many more political systems with ideal view to build, the more we will move away to the essence of life. The ideal of a political society would be less politics.

Conformism with naivety of public opinion will be the premise of a power that wills absolutes everything. This would be a perfect environment for the demagogues to take advantage, which satisfy the crowd, we manipulate that, by abusing in interest of personal egos. Tyranny of the majority fundamentally differs from a tyrant, the conversion of the power from public purpose to fulfil the personal whims. So, let's return to the tyrant sovereign that his freedom, his individuality makes guidance (compelling) for each other person. Social homogeneity, social objectivism it is indicative for a totalitarian (hermetic) mind. Where the sovereign has the power, but has not right. This is "the cult of the leader" that his point of view for the world, he wears to the all humankind.

The maxims of liberalism of Mill would become a warning for totalitarian systems in XX century. Even in the ideas, he is part of discourses of the political philosophy that characterised the time after him. In conclusion, we have to remember! The truth as well as the power are not owned, those are co-created. Naturally, their use requires the skills of art that melts in harmony all diversity parts of co-creators.

\section{Biblography}

Bentham. J, Mill. J. S, “Utilitarzimi dhe shkrime të tjera”, IPS\&DITA 2000, Tiranë 2006

Spencer. H, "Njeriu kundër shtetit", IPLS\&DITA 2000, Tiranë 2006

Kymlicka. W, "Contemporary political philosophy", Oxford University Press, 2002

Kalemaj. E, "Demokracia dhe rreziku i oklokracisë", Buletin shkencor, Universiteti 'Fan S. Noli', nr. 27, issn:2078-7111, f, 7-18, Korçë 2014.

Douglas Moggach School of Political Studies and Department of Philosophy University of Ottawa March 2007, f, 1-37

C. E. Merriam, Jr. History of the Theory of Sovereignty since Rousseau Batoche Books Kitchener Ontario Canada ISBN: 1-55273-062-X, 2001.

Kamitake. Yoshiro, "From democracy to ochlocracy", Hitosubashi Journal of Economics nr. 48, 2007, p; 83-93

Berlin. I, 2003 "Idetë filozofike të shekullit XX", Tiranë, Botimet "Onufri

Mill. J. S, "Mbi lirinë", Julvin 2, ISBN: 978-9928-137-31-9, Tiranë 2014

Nagle. J. D, "Comparative Politics, political system performance in three worlds", Nelson - Hall Publishers, ISBN: 0-83041299-9, Chicago 1992

Huemer. M, "The problem of political authority", Palgrave Macmillan, ISBN: 978-1-137-28164, New York 2013 